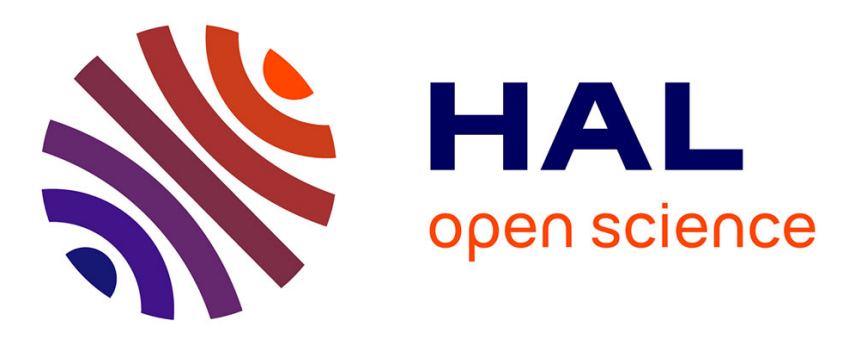

\title{
Les hausses récentes des cours des matières premières traduisent-elles l'entrée dans un régime de prix plus élevés ?
}

Cécile Couharde, Vincent Geronimi, Armand Taranco

\section{To cite this version:}

Cécile Couharde, Vincent Geronimi, Armand Taranco. Les hausses récentes des cours des matières premières traduisent-elles l'entrée dans un régime de prix plus élevés ?. Revue Tiers Monde, 2012, 211 (3), pp.13. 10.3917/rtm.211.0013 . hal-03171468

\section{HAL Id: hal-03171468 \\ https://hal.science/hal-03171468}

Submitted on 16 Mar 2021

HAL is a multi-disciplinary open access archive for the deposit and dissemination of scientific research documents, whether they are published or not. The documents may come from teaching and research institutions in France or abroad, or from public or private research centers.
L'archive ouverte pluridisciplinaire HAL, est destinée au dépôt et à la diffusion de documents scientifiques de niveau recherche, publiés ou non, émanant des établissements d'enseignement et de recherche français ou étrangers, des laboratoires publics ou privés. 


\section{RECENT TRENDS IN AGRICULTURAL COMMODITY PRICES: CHALLENGES FOR DEVELOPMENT AND FOOD SECURITY}

Do Recent Increases in Commodity Prices Indicate Entry into a Higher Price Regime? Cécile Couharde, Vincent Geronimi , Armand Taranco

Armand Colin | « Revue Tiers Monde »

2012/3 No $211 \mid$ pages 13 - 34

ISSN 1293-8882

ISBN 9782200928070

This document is a translation of:

Cécile Couharde et al., «Les hausses récentes des cours des matières premières traduisent-elles l'entrée dans un régime de prix plus élevés ? », Revue Tiers Monde 2012/3 (No 211), p. 13-34. DOI 10.3917/rtm.211.0013

\section{Translated from the French by JPD Systems}

\section{Available online at :}

http://www.cairn-int.info/article-E_RTM_211_0013--recent-trends-in-agriculturalcommodity-.htm

\section{How to cite this article :}

Cécile Couharde et al., «Les hausses récentes des cours des matières premières traduisent-elles l'entrée dans un régime de prix plus élevés ? , Revue Tiers Monde 2012/3 (No 211), p. 13-34. DOI 10.3917/rtm.211.0013

Electronic distribution by Cairn on behalf of Armand Colin.

(C) Armand Colin. All rights reserved for all countries.

Reproducing this article (including by photocopying) is only authorized in accordance with the general terms and conditions of use for the website, or with the general terms and conditions of the license held by your institution, where applicable. Any other reproduction, in full or in part, or storage in a database, in any form and by any means whatsoever is strictly prohibited without the prior written consent of the publisher, except where permitted under French law. 


\title{
RECENT TRENDS IN AGRICULTURAL COMMODITY PRICES: CHALLENGES FOR DEVELOPMENT AND FOOD SECURITY
}

\section{DO RECENT INCREASES IN COMMODITY PRICES INDICATE ENTRY INTO A HIGHER PRICE REGIME?}

\author{
Cécile Couharde ${ }^{\star}$, Vincent Geronimi ${ }^{* \star}$, Armand Taranco $^{\star * \star}$
}

In this article we seek to determine whether the recently observed increases in commodity prices, and more specifically in agricultural food commodities, reflect a regime switch to higher price levels. To answer this question, we study the dynamics of the terms of trade of commodities and more specifically of agricultural food commodities in the period 19002010 using the Kalman filter and Markov regime-switching models. Our results support the hypothesis that the terms of trade of commodities have moved into a new regime since 2006 and those for agricultural food commodities followed in 2008, characterized by an average price level over $50 \%$ greater than those which prevailed over the period 1986-2005 for commodities and 1986-2007 for agricultural food commodities.

Keywords: agricultural food commodities, commodities prices, Kalman filter, Markov regime switching models.

The 2000s witnessed a dramatic rise in world commodity prices, notably in basic foods. The nature of the rise is subject to varying interpretations, one of which assigns a persistent character to the phenomenon, indicative of a change in the dynamics of prices towards new, higher levels. This interpretation is in direct contradiction with the hypothesis of deterioration in the terms of trade for commodities over the long term, established by Prebisch

\footnotetext{
* EconomiX-CNRS, Université de Paris Ouest Nanterre La Défense. cecile.couharde@u-paris10.fr

** CEMOTEV, Université de Versailles Saint Quentin. vincent.geronimi@uvsq.fr

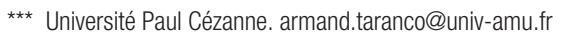


(1950) and Singer (1950). According to the Prebisch-Singer (PS) hypothesis, the prices of commodities increase less rapidly than those of manufactured goods, through the interplay of income and price elasticities, and by different transmission effects of productivity gains between the two sectors. Productivity gains result in lower commodity prices and higher wages in the manufacturing sector as a result of organized labor markets. Nonetheless, what we have seen in recent times - namely, rising terms of trade for commodities - is mainly due to a more sustained rise in their nominal prices compared to those of manufactured goods.

The argument over the persistent increase in the level of commodity prices (since 2005) has led to several explanations which can be categorized depending on whether they refer to factors of demand, supply, or market organization (Economic, Social, and Environmental Council 2008; Daviron et al. 2011; Prakash 2011; Chalmin 2011). The principal factor influencing demand can be easily traced to the rise of emerging countries, such as China and India, in international commodity trading. The salient supply factors concerning are organized around the theme of ecological transition. The third factor is the financialization of commodity markets. These three explanatory factors can be interpreted as the manifestation of a new stage of globalization, characterized by a tendency toward the depletion of natural resources and the exhaustion of farmland productivity, coupled with the negative impacts of climate change all in the context of a profound shift in international hierarchical structures and the increased financialization of the markets for commodities.

Of course, these arguments suffer from a number of limitations. First, the rise of emerging economies does not only translate into an increase in demand (the myth of the "all-devouring" new economies), but comes hand in hand with an increase in supply on international markets (as the wheat market, for example, amply illustrates). Additionally, the expansion of demand in emerging markets has an effect on the prices of manufactured goods, such that the final impact on trends in real commodity prices is a priori indeterminable (Radetsky 2006). Second, the argument of ecological transition also appears equivocal. References to the existence of a fixed limit on nonrenewable resources have been shown in the past to be ineffective in justifying the price movements of commodities (Economic, Social, and Environmental Council 2008). The introduction of substitutes, the role of technical progress, and new discoveries have led to progressive extensions of such limits. On the other hand, the increased use of bio-fuels may in part explain the upward trend in the prices of food substitutes. Climate change itself plays in both directions, favoring certain regions in certain cases. The financialization of commodity markets may not necessarily lead to long-term rising prices although it may, under certain conditions, lead to an increase in price volatility (Balcombe 2011). Finally, the hypothesis that the commodity price rises are indicative of 
a new long-term bullish momentum remains heavily debated. Until now, no empirical study has shown that price developments in the recent period reflect any break and/or change in price dynamics.

The objective of this article is to analyze the nature of the recent rise in commodity prices, especially for agricultural food commodities, over the long term. Specifically, we seek to determine whether the recently observed increases reflect a change in the dynamics of prices to new, higher levels. To answer this question, we adopt an approach which is substantially distinct from previous work in several ways. First, we extend until 2010 the annual primary commodity price index originally developed by Grilli and Yang (1988), that was later extended to 1998 by Cashin, Liang, and McDermott (1999), and then to 2007 by Pfaffenzeller, Newbold, and Rayner (2007). We then use the Kalman filter approach to study the dynamics of these terms of trade. Using this approach allows us to specify the respective contributions of cycles and trends in the development of terms of trade, and, beyond that, to test and identify any departures (or "breaks") from those trends. ${ }^{1}$ We shall then attempt to discern whether the breaks found are structural in nature, that is, whether they reflect a persistent change in the dynamics of commodity prices. To clarify the nature of these breaks and the price dynamics they define, we will call upon Markov switching models, taking our inspiration from pioneering work undertaken in the study of the evolution of interest rates (Hamilton 1988) and American GDP growth rates (Hamilton 1989). ${ }^{2}$ This second approach makes it possible to provide answers to the question of the nature of the breaks and price dynamics seen in the 2000s. Finally, we pay special attention among commodities to agricultural food commodities. Rising food prices, along with those of commodity prices as a whole since 2005 , have resulted in the resurgence of food crises. While these have most often been analyzed as resulting from short-term shocks, especially for certain products such as corn, millet, and sorghum, and negative supply shocks on agricultural production due to insufficient rainfall in some producing regions of the Sahel, they may nonetheless mask a longer term movement towards higher prices. Such developments raise serious questions concerning food security and, by extension, supplyside policies beyond those of price stabilization.

The rest of the paper is organized as follows. The first part presents a review of the empirical literature, drawing the principal lessons to be learned from the main methods for estimating the evolution of commodity prices. In the second

\footnotetext{
1. These breaks notably reflect a change in the main estimated parameters of the model (trend, level, and variance). Such breaks are distinct from potential outliers. See Appendix 4.

2. Analysis of the expansionary and recessionary phases of the American economic cycle led Hamilton to propose a Markov regimeswitching model in 1989. In the original design, Hamilton suggested that the economy could be in one of two states. The economy could thus pass from one state to another or remain in one state with a certain probability. Since that time, Markov state-switching models have undergone many generalizations. The article by Teräsvirta (2006) provides a review of these different models.
} 
part, we use a Kalman filter to analyze the dynamics of the terms of trade for commodities in general and agricultural food commodities in particular. We test, notably, for possible break dates. To clarify the nature of the different dynamic regimes in place between these dates, we turn to Markov switching models in the third section.

\section{RECENT DEVELOPMENTS IN THE TERMS OF TRADE OF COMMODITIES: METHODS OF ESTIMATION}

The first lesson to be learned from the literature is that caution in the interpretation of fluctuations in commodity prices is essential. Economic models (Hotelling 1931; Gustafson 1958; Ezekiel 1938) have proved sadly ineffective in predicting price movements (Stigler 2011), a situation which has often led to "absurd" economic policy recommendations (Deaton 1992; World Bank 1988). Elsewhere, the results of empirical analyses that have multiplied since the preliminary work of Cuddington and Urzua (1989) have led to ardently debated conclusions. Echoing the findings of many older works (e.g., Bleaney and Greenaway 1993; Deaton 1992; Deaton and Laroque 2002), Stigler (2011) notes that "a fundamental understanding of commodity prices - especially between theory and empiricism - is lacking."

This lack of understanding of the dynamics of price movements reflects the high degree of uncertainty associated with them. Recent studies of price volatility provide some answers, by providing a measure of this uncertainty, notably with work by Balcombe (2011) and Roache (2010). Prakash (2011) presents the principal result of the empirical literature: "There appears to be irrefutable evidence of a secular rise in uncertainty for traded commodities key to food security" (8).

While the PS hypothesis seems to be subject to unambiguous measurements that would settle the debate, publications and econometric work on this topic from more recent decades have been unable to provide a united response to it. The work of the 2000s on the analysis of the long-term change of commodity prices confirms the difficulty of asserting the existence of a continuous downward trend in the terms of trade for commodities.

Among the attempts to empirically verify the PS hypothesis, the articles of Grilli and Yang (1988) and Cuddington and Urzua (1989) formed a collection of literature on the subject, which would continue to grow. Grilli and Yang (1988) reconstructed series of price indexes over the long term and provided a new standardized index of changes in real commodity prices. ${ }^{3}$ Calculated

\footnotetext{
3. See Appendix 2.
} 
as the ratio of the indices of commodity prices to the price indices for the manufactured exports of developed countries, these real prices, or "terms of trade," provide a way to measure the power to purchase imported manufactured goods that developing countries (specialized in commodities) have, based on income from their exports. Changes in the terms of trade of commodities appears to be central to the development prospects of these countries. Grilli and Yang (1988) use a linear regression to investigate how the terms of trade of commodities vary with time. Their results confirm the existence of a secular (albeit very slow) trend of declining terms of trade at around $0.5 \%$ per year. Cuddington and Urzua (1989) revisit the PS hypothesis using time series econometrics, notably employing unit root tests. These tests show whether commodity prices do or do not converge to a long-term historical average. Cuddington and Urzua (1989) exploit in particular the tests of Dickey-Fuller (1981) and those proposed by Beveridge and Nelson (1981). The Dickey-Fuller tests enable them to test the stationary or non-stationary nature of their series, which are either stochastic (the Difference Stationary, DS, model) or deterministic (the Trend Stationary, TS, model). The Beveridge and Nelson tests allow them to distinguish a trend component (expressed using random walks) and a cyclical component (characterized by a stationary series).

In contrast to previous literature, Cuddington and Urzua (1989) developed a representation of the evolution of the terms of trade according to a DS model. This has two major implications. On the one hand, by rejecting the TS model, they demonstrate the absence of any deterministic trend in the evolution of the terms of trade. The initial question raised by the PS hypothesis then become moot. On the other hand, the nature of the fluctuations in commodity prices needs to be reconsidered. When the representative model is of the TS type, the effects of any shocks are only temporary. However, when the representative model of the process underlying the series of observations is of the DS type, any shock has a permanent impact on all future periods. By undertaking this change in perspective, Cuddington and Urzua (1989) opened discussion on the importance of the fluctuations themselves. Having shown that we cannot reject the hypothesis of the existence of a unit root (DS model) for almost all commodity prices, Cuddington and Urzua (1989) proceeded to break down their series into two components, one permanent (trend), and one temporary (cyclical), using the Beveridge Nelson model. The conclusion from their study confirms the importance of the persistence of fluctuations in terms of trade: $39 \%$ of the variation of the terms of trade are in fact permanent, while $61 \%$ are cyclical and disappear after three years.

Their paper gave impetus to two directions for research. One would focus on the nature of the most appropriate model for representing the evolution of commodity prices (TS versus DS), while the other would focus on the characterization of the fluctuations, in particular on measurements of their persistence. 
These two lines of research led to the development of studies undertaken commodity by commodity, but especially to an important consideration of the best way to integrate any breaks in the level or trends of prices (León and Soto 1997; Kim et al. 2003). If these latter considerations are omitted, an incorrect diagnosis may well result. As Perron (1989) has shown, a small number of trend breaks can generate processes that appear to have unit roots. Thus, León and Soto (1997), incorporating the possibility of structural breaks in the level and slope of commodity prices, challenge the results provided by Cuddington and Urzua (1989). According to these authors, most commodity prices follow a stationary process around a deterministic trend, once a structural break in the level or trend of commodity prices is integrated.

In the debate on the TS or DS character of changes in commodity prices, studies tend to consider only a rather small number of breaks. Thus, the first works incorporating exogenous break dates in the spirit of Perron's first articles (1989), consider no more than three breaks. Sapsford, Sarkar, and Singer (1992) identify an upward break, in level, in 1950. Bleanay and Greenaway (1993), meanwhile, isolate a downward break in price levels of some $37 \%$ in 1980. Powell (1991) identifies three breaks, also downward, in price levels occurring in 1921, 1938, and 1975. Ocampo and Parra (2003) successively examine three types of breaks using the Perron test (1997) $)^{4}$ : an exogenous break in level and trend in $1920,{ }^{5}$ a break in level and trend in 1944, and a break in the trend in 1978. Studies taking into account the presence of endogenous breaks consider a maximum of two breaks. ${ }^{6}$ Thus, using the Zivott and Andrews sequential test (1992), Leon and Soto (1997) identify a single endogenous break. Results from a study by Zanias (2004), based on the Lumsdaine and Papell test (1997), isolate two downward breaks in price levels for the period 1900-1998, occurring in 1920 and 1984.

While these studies have in common the series of real prices for commodities developed by Grilli and Yang (1988), the differences between the results obtained are mainly due, as highlighted by Bleanay and Greenaway (1993), to the period of time and the particular samples of commodities considered. It does appear that the evolution of commodity prices in the long term is characterized by a nonlinear dynamic which takes the form of a stairway downwards until the middle of the first decade of the 2000s. According to Zanias (2004), three steps down followed one another throughout the entire 20th century, based on two breaks in level, one in 1920 and the other in 1984. By extending

\footnotetext{
4. In this case, Ocampo and Parra (2003) consider three types of structural breaks successively (trend, level, or trend and level simultaneously) based on Perron's work (which only takes into account one endogenous structural break).

5. From the analysis of residues of a deterministic trend model, or exogenously.

6. The tests by Zivot and Andrews (1992) and Perron (1997) allow for the integration of an endogenous break into the level or slope of commodity prices, the null hypothesis being the absence of structural breaks. The Zivot and Andrews (1992) study is extended to the case of two endogenous breaks by Lumsdaine and Papell (1997).
} 
the results of this work, the increase in prices from the second half of the 2000s could then reflect a possible break into a new level of higher prices. Such a change would be without precedent during the 20th century.

To test this hypothesis, we have implemented two methodologies. We employ the Kalman filter to detect the presence of such breaks, and the Markov regime switching model to confirm the possible arrival of a new level of high prices for commodities. According to the calculation method presented by Pfaffenzeller et al. (2007), we have extended until 2010 the annual series of price indices of commodities (including agricultural food commodities) as well as the annual series of price indices of manufactured exports from developed countries. ${ }^{7}$ The price indices of commodities and agricultural food commodities are calculated in accordance with previous studies (Grilli and Yang 1988; Cashin and McDermott 2002; Pfaffenzeller et al. 2007), respectively as the weighted average of price indices of twenty-four commodities and eleven food products. ${ }^{8}$

\section{DETECTION OF STRUCTURAL BREAKS USING THE KALMAN FILTER}

We first examine the dynamics of the terms of trade of commodities and more specifically of agricultural food commodities with the Kalman filter. ${ }^{9}$ The Kalman filter has already been applied to commodity prices (Harvey et al. 2010; Reinhart and Wickham 1994; Geronimi, Mathieu, and Taranco 2003, 2007). This approach can provide answers to the question of the nature of fluctuations in commodity prices. More specifically, the application of this filter to the changing terms of trade helps to determine the respective contributions of their permanent and cyclical components, while raising a number of statistically interesting considerations. ${ }^{10}$ Beyond confirming the decisive influence of fluctuations in the trend compared to fluctuations around the trend, we have also used the Kalman filter to detect endogenously the presence of breaks in the evolution of commodity prices. ${ }^{11}$

Figure 1 shows the evolution of the components of the terms of trade of commodities since 1900. It is clear that the levels were historically low in the late 1980s and early 2000s. This finding is consistent with that already established

\footnotetext{
7. In line with the literature on the Prebisch-Singer hypothesis, we use annual data. Monthly and quarterly data are not available for all raw materials before 1957. As we are interested in the dynamics of the medium and long terms, additional information provided by data below the annual level is not crucial for our purposes.

8. See Appendix 2 for the different sources.

9. See Appendix 3 for a presentation of the method.

10. In particular, the Kalman filter can treat non-stationary series in some cases by modifying the initialization parameters. Moreover, the ARMA processes appear as a special case of the Kalman filter. Finally, the coefficients of the model can evolve and are not necessarily considered invariant during the estimation period.

11. See Appendix 3 for the method of detecting structural breaks.
} 
in 1994 by Reinhardt and Wickham (1994). The low level attained in 1992 lasted until the middle of the first decade of the 2000s. However, this result does not allow us to conclude that a continuous downward trend of commodity prices is necessarily at work. The study of the various components of these prices through the use of the Kalman filter goes on to clarify this last point. Figure 1 clearly shows that the level of the cyclical component (the difference between the level measured and the trend component of Figure 1) is much lower than the trend component. Thus, fluctuations in commodity prices are mainly due to fluctuations in the trend and less to fluctuations around the trend (the cyclical and irregular component). ${ }^{12}$ Relying on the annual data, our results are close to those obtained by Reinhart and Wickham (1994) using quarterly data for the period 1957-1992. The historical low point in the general index of commodity prices reached in 1994 is then an expression of the trend, and not a transitory phenomenon explained by the cyclical component. This conclusion is consistent with those obtained in the literature on all twenty-four prices of individual commodities, as well as in composite indices for the period 1957-2003 (Geronimi et al. 2007).

Figure 1: Changes in the terms of trade of commodities. Trend, cycles, and structural breaks (logarithm, 1900-2010)

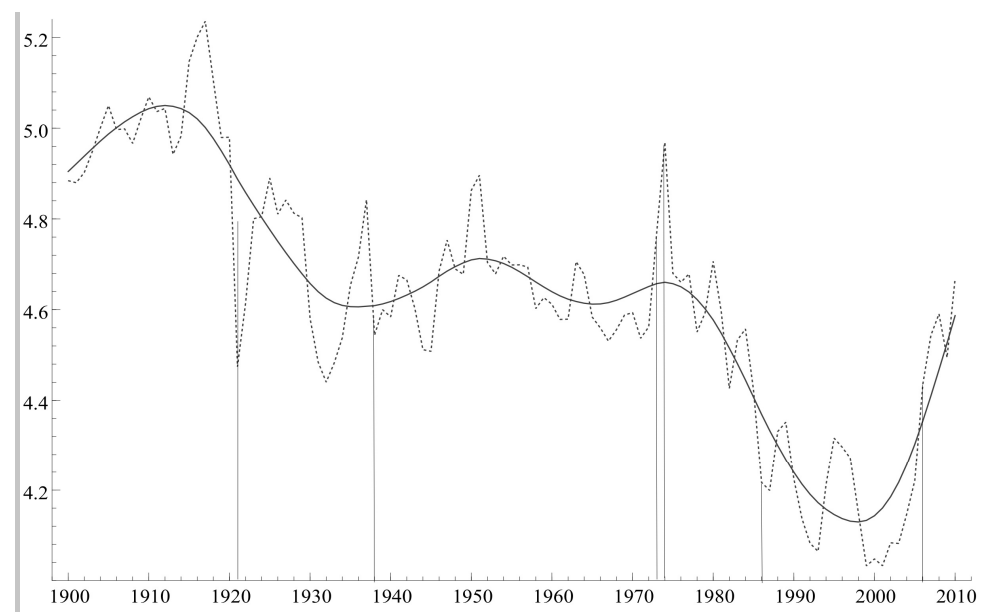

Notes: logarithm of the terms of trade in commodities (dotted line) and the trend component (solid line). Structural breaks: 1921, 1938, 1973, 1974, 1986, 2006.

Source: Authors' estimates based on an extension of the series of Pfaffenzeller, Newbold, and Rayner (2007).

Agricultural food commodities have a special place among commodities. Unlike other products, they are renewable natural resources, subject to specific, notably climatic, shocks. However, as seen in Figure 2, the terms of

12. The cyclical component represents on average $5.7 \%$ of the trend component. The irregular component is not significant. 
trade of agricultural food commodities follow a similar dynamic to the terms of trade of all commodities over the long term. The factors that influence the evolution of these prices are, in fact, similar to those outlined in the literature to explain the rise in commodity prices (see table in Appendix 1).

Figure 2: Changes in the terms of trade of agricultural food commodities.

Trend, cycles and structural breaks (logarithm, 1900-2010).

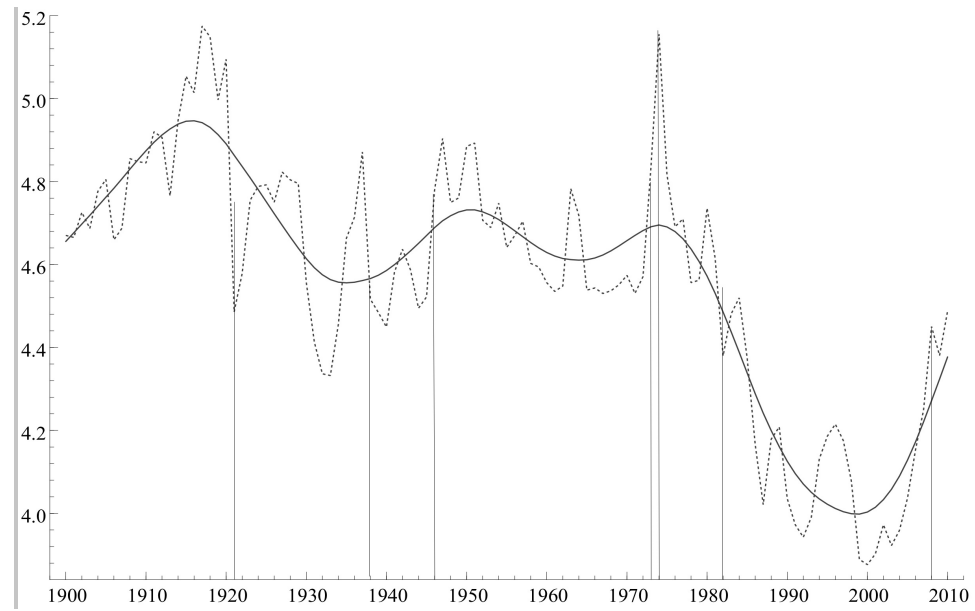

Notes: logarithm of the terms of trade in agricultural food commodities (dotted line) and the trend component (solid line).

Structural breaks: 1938, 1946, 1973, 1974, 1982, 2008.

Source: Authors' estimates based on an extension of the series of Pfaffenzeller, Newbold, and Rayner (2007).

The study of auxiliary residuals ${ }^{13}$ on the level of the trend of the same series of terms of trade for commodities and agricultural food commodities allows break dates over the period 1900-2010 to be detected. These dates, given in Table 1, coincide with those found in the literature (Ocampo and Parra 2003; Powell 1991; Zanias 2004). However, our estimates bring a new element into consideration. Taking into account the evolution of commodity prices until 2010 leads to the detection of a new break, in 2006 for all commodities under examination and in 2008 for agricultural food commodities. 
Table 1: Detection of breaks (dates, t-value, and p-value, 1900-2010)

\begin{tabular}{|c|c|c|c|c|c|}
\hline \multicolumn{3}{|c|}{ Terms of trade of all commodities } & \multicolumn{2}{c|}{ Terms of trade of agricultural food commodities } \\
\hline Dates & $\mathrm{t}$-value & $\mathrm{p}$-value & Dates & $\mathrm{t}$-value & $\mathrm{p}$-value \\
\hline 1921 & -4.61036 & 0.00001 & 1921 & -4.46787 & 0.00001 \\
\hline 1938 & -2.23779 & 0.01362 & 1938 & -2.04003 & 0.02186 \\
\hline 1973 & 2.09790 & 0.01909 & 1946 & 2.08880 & 0.01951 \\
\hline 1974 & 2.26931 & 0.01259 & 1973 & 2.23093 & 0.01385 \\
\hline 1975 & -1.94624 & 0.02708 & 1974 & 2.77848 & 0.00321 \\
\hline 1986 & -1.90342 & 0.02979 & 1982 & -2.13139 & 0.01763 \\
\hline 2006 & 2.14158 & 0.01721 & 2008 & 1.81292 & 0.03627 \\
\hline
\end{tabular}

Note: results obtained from auxiliary residuals of the Kalman filter, on the logarithm of data. All break dates concern the price level and are significant at the 3.6\% threshold, where a break appears in 2008 for the price of agricultural food commodities.

Source: Authors' estimates based on the extension of the series of terms of trade updated by Pfaffenzeller et al. (2007).

The existence of these breaks undermines the PS hypothesis of a longterm downward trend covering all commodities. The principal debate is then around the existence and significance of these breaks. The upward changes to higher commodity prices since 2005 reinforce doubts regarding whether or not the hypothesis of the existence of a deterministic downward trend over time is valid. These recent developments seem to be the manifestation of the existence of breaks in the 2000s, corresponding to a transition period between different price regimes.

\section{WHAT ARE THE PRICE DYNAMICS OF THE LATE 2000S?}

To clarify the nature of these breaks and the price regimes they define, we have implemented a Markov switching model. In such a model, the dynamics of variables potentially change regime in each period of time as a function of the concomitant real economic conditions. It is therefore possible to identify, endogenously, periods corresponding to structural breaks defining the succession of different regimes.

Here we consider a Markov Switching Dynamic Regression mode ${ }^{14}$ with a constant and common variance proper to each regime. ${ }^{15}$ This representation allows us to differentiate each regime by the average index of the terms of trade and thus to test whether the recent rise in the terms of trade are

14. MS-DR: Dynamic Markov Switching Regression. See Appendix 4 for the presentation of the methodology.

15. A Wald test (in the form of linear restrictions) was applied to the equality of variances and showed that the variances are not significantly different in the different periods of analysis. Results available from the authors. 
or are not a consequence of a movement in the dynamics of prices toward higher levels.

In such models, the number of regimes should be determined exogenously, which is a limitation. However, too many different dynamic regimes lead to the non-convergence of the algorithm, which sets an upper limit to the number of possible regimes. Here, we consider a model with three regimes rather than two. Our goal is not to test the time sequence of two regimes associated respectively with the high and low levels of the terms of trade; rather, we seek to identify different regimes in accordance with representations made by Zanias (2004) and consistent with the dates of breaks previously identified using the Kalman filter.

Figure 3: Switch of regime in the level of the terms of trade for all commodities (with common variance, 1900-2010)

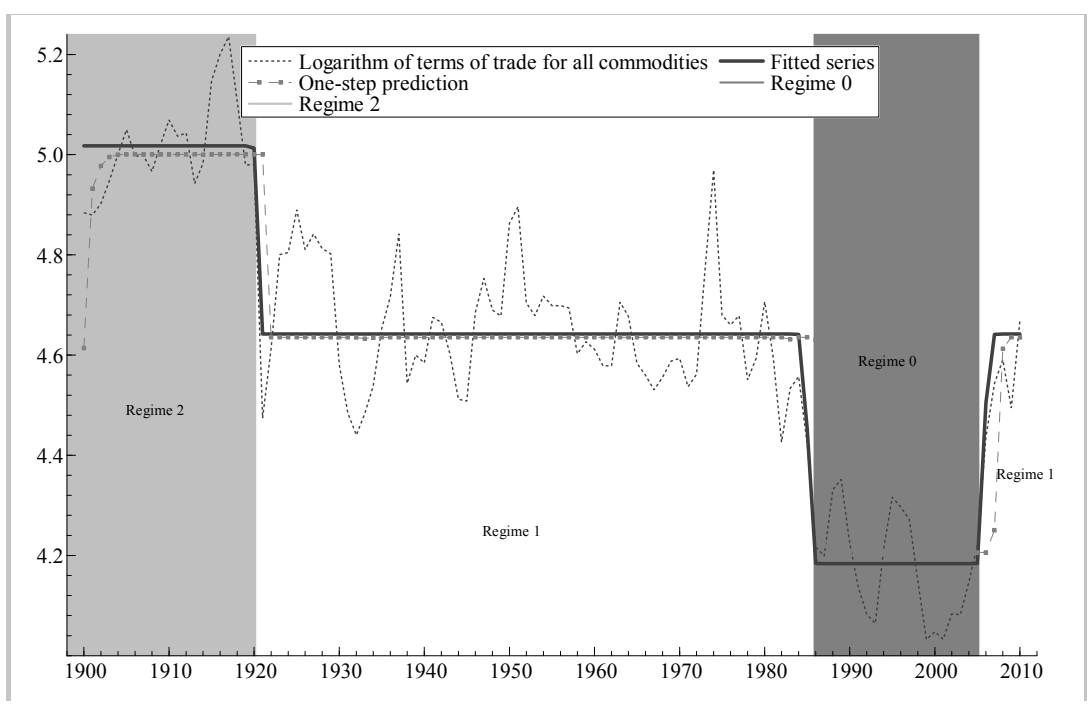

Source: Authors' estimates based on an extension of the series of Pfaffenzeller, Newbold, and Rayner (2007). See Appendix 4 for the methodology.

The results of a three-regime model based on the terms of trade of commodities are shown in Figure 3 and Table 2. ${ }^{16}$ 
Table 2: Classification of periods, the terms of trade of commodity prices, and the Markov model with three regimes (common variance, 1900-2010)

\begin{tabular}{|c|c|c|c|c|c|}
\hline Regime & $\begin{array}{c}\text { Principal } \\
\text { characteristics }\end{array}$ & Periods & $\begin{array}{c}\text { Mean } \\
\text { duration } \\
\text { (years) }\end{array}$ & Commonvariance & Constant \\
\hline Regime 0 & Low terms of trade & $1986-2005$ & 20 & 0.113213 & 65.62 \\
\hline Regime 1 & Medium terms of trade & $\begin{array}{c}1921-1985 \\
\mathbf{2 0 0 6 - 2 0 1 0}\end{array}$ & 35 & 0.113213 & 103.78 \\
\hline Regime 2 & High terms of trade & $1900-1920$ & 21 & 0.113213 & 151.05 \\
\hline
\end{tabular}

Source: Authors' calculations from the logarithms of the index of the terms of trade $(1977-1979=100)$. See Appendix 4 for the presentation of the model and the estimation of the transition matrix. The constant for each of the three regimes is the average value of the terms of trade.

The representation in the form of a stairway descending to 2005 that we obtain (Figure 3) is in line with that found by Zanias (2004), but uses a different methodology. Furthermore, our results confirm the relevance of the break dates obtained previously using the Kalman filter. In particular, our results support the hypothesis of a change in dynamic regime from 2006 onwards. It appears similar to that which characterized the period 1921-1985 (Regime 1, in white in Figure 3). It is characterized by the absence of a trend and a significantly higher level of prices (56\% higher) than that associated with the dynamic regime of the following period, between 1986 and 2005.

As shown in Table 2, the dynamic regime established beginning in 2006 is characterized by an average index of the terms of trade of commodities of 103.78 (base 100 in 1977-1979) compared to 65.62 in the period 1986-2005 and 151.05 in the 1900-1920 period. Thus, the hypothesis that the terms of trade of commodities have been moving to a permanently higher level since the middle of the first decade of the 2000s is supported by these initial results. ${ }^{17}$

The terms of trade of agricultural food commodities share identical characteristics to those of commodities, especially with regard to the exceptionally low level of the terms of trade over the period 1986-2007 (Figure 4 and Table 3). We identify, from 2008, a new regime (regime 1) which has the same characteristics as that which prevailed in particular over the periods 1955-1972 and 1977-1985 (Table 3). This regime is characterized by an average index of the terms of trade of agricultural food commodities of more than $65 \%$ compared to the previous regime (1986-2007, regime 0).

17. The analysis of the transition matrix of each index shows high persistence for each regime and a very low probability of transition from one regime to another. 
Figure 4: Switch of regime in the level of the terms of trade in agricultural food commodities (common variance, 1900-2010)

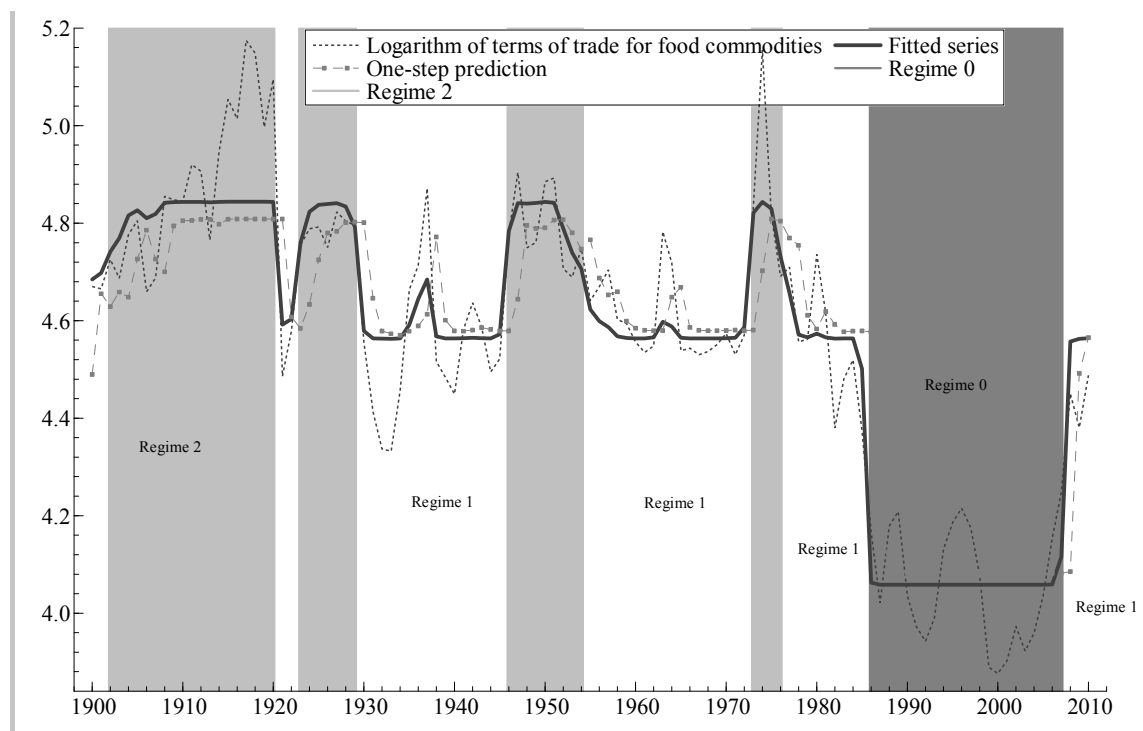

Source: Authors' estimates based on an extension of the series of Pfaffenzeller, Newbold, and Rayner (2007). See Appendix 4 for the methodology used.

Table 3: Classification of periods, the terms of trade for agricultural food commodities, and the Markov model with three regimes

(common variance, 1900-2010)

\begin{tabular}{|c|c|c|c|c|c|}
\hline Regime & $\begin{array}{c}\text { Principal character- } \\
\text { istics }\end{array}$ & Periods & $\begin{array}{c}\text { Mean dura- } \\
\text { tion (years) }\end{array}$ & Commonvariance & Constant \\
\hline Regime 0 & Low terms of trade & $1986-2007$ & 22.0 & 0.125843 & 57.89 \\
\hline & & $1900-1901$ & & & \\
& & $1921-1922$ & & & \\
& & $1930-1945$ & 8.33 & 0.125843 & \\
& & $1955-1972$ & & & \\
& & $1977-1985$ & & & \\
\hline \multirow{3}{*}{ Regime 1 } & Medium terms of trade & $1902-1920$ & & & \\
& & $1923-1929$ & & & \\
& & $1946-1954$ & 9.75 & 0.125843 & \\
& & & & & \\
\hline
\end{tabular}

Source: Authors' calculations from the logarithms of the index of terms of trade of food products (1977-1979 $=100$ ). See Appendix 4 for the presentation of the model and the estimation of the transition matrix. The constant for each of the three regimes is the average value of the terms of trade. 
Overall, the hypothesis of a movement in dynamic regime at the end of the period (from 2008) toward a higher level of prices is again strengthened for the terms of trade of agricultural food commodities.

On the other hand, while the dynamic regimes follow one another sequentially in the case of the terms of trade of commodities, they overlap in the case of the terms of trade for agricultural food commodities, except for the regime established over the period 1986-2007. This appears as a unique period, characterized by the lowest average index of the terms of trade over the period 1900-2010. The average duration of the regime during which agricultural food prices break at the end of the period is thus more limited ( 8.33 years), compared to that of the regime that includes all commodities from 2006 (35 years).

\section{CONCLUSION}

The lessons that can be drawn from the literature and long-term analysis of recent developments in the terms of trade for commodities support the idea that the second half of the 2000s corresponds to a period of structural break revealing a change in price dynamics. The results presented here are thus in line with the hypothesis that the terms of trade of commodities and more specifically of agricultural food commodities have entered a new regime characterized by higher prices than those prevailing in the period 1986-2006. Across the whole period 1900-2010, this is an unprecedented development. The thesis that the 2000s witnessed a new phase of globalization, characterized by ecological transition, progressive shifts in the international hierarchy, and the financialization of commodity markets, is thereby partially reinforced. Further work is required to explore the implications of this thesis for developing countries with primary specializations, which had faced decreasing terms of trade throughout the entire 20th century. Leaving a regime of unusually low prices during the period 1986-2006 can thus be seen as an opportunity for development of the countries that are least developed in primary specialization. For agricultural food commodities, classically studied in terms of short-term fluctuations, the findings concerning price levels are similar. The beginning of a regime characterized by higher price indices, if confirmed, raises questions regarding the food security of the poorest populations. 


\section{BIBLIOGRAPHY}

Balcombe, Kevin. 2011. "The Nature and Determinants of Volatility in Agricultural Prices: An Empirical Study." In Safeguarding Food Security in Volatile Global Markets, edited by Adam Prakash, 91-112. Rome: FAO.

Beveridge, Stephen, and Charles R. Nelson. 1981. "A New Approach to Decomposition of Economic Time Series into Permanent and Transitory Components with Particular Attention to Measurement of the Business Cycle." Journal of Monetary Economics 7, 2: 151-174.

Bleaney, Michael, and David Greenaway. 1993. "Adjustment to External Imbalance and Investment Slumps in Developing Countries." European Economic Review 37, 2-3: 577-585.

Cashin, Paul, Hong Liang, and C. John McDermott. 1999. "How Persistent are Shocks to World Commodity Prices?" IMF Working Paper 99/80, International Monetary Fund.

Cashin, Paul, and C. John McDermott. 2002. "The Long-Run Behavior of Commodity Prices: Small Trends and Big Variability." IMF Staff Papers 49, 2: 175-199.

Chalmin, Philippe, ed. 2011. Les Marchés mondiaux 2011. Paris: Economica "Cyclope" collective.

Conseil économique, social et environnemental. 2008. Les Marchés des matières premières: évolution récente des prix et conséquences sur la conjoncture économique et sociale. Paris: Editions des Journaux Officiels.

Cuddington, John T., and Carlos M. Urzua. 1989. "Trends and Cycles in the Net Barter Terms of Trade: A New Approach." Economic Journal 99: 426-442.

Daviron, Benoit, Nango Dembele, Sophia Murphy, and Shahidur Rashid. 2011. Report on Price Volatility. Rome: Committee on World Food Security.

Deaton, Angus S. 1992. "Commodity Prices, Stabilization, and Growth in Africa." Discussion Paper 166, Princeton University.

Deaton, Angus S., and Guy Laroque. 2003. "A Model of Commodity Prices After Sir Arthur Lewis"
Journal of Development Economics 71, 2: 289310.

Géronimi, Vincent, Laurent Mathieu, and Armand Taranco. 2003. "La Nature des fluctuations des cours des matières premières." Économie et Sociétés 37, 9, September.

Géronimi, Vincent, Laurent Mathieu, and Armand Taranco. 2007. "Les Cours internationaux des produits agricoles: tendances et cycles." In $\mathrm{La}$ Régulation des marchés agricoles internationaux, edited by Jean-Marc Boussard and Hélène Delorme, 27-52. Paris: L'Harmattan.

Grilli, Enzo R., and Maw Cheng Yang. 1988. "Primary Commodity Prices, Manufactured Goods Prices, and the Terms of Trade of Developing Countries: What the Long Run Shows." The World Bank Economic Review 2, 1: 1-47.

Gustafson, Robert L. 1958. "Implications of Recent Research on Optimal Storage Rules." Journal of Farm Economics 40, 2: 29-300.

Hamilton, James D. 1988. "Rational Expectation, Econometric Analysis of Changes in Regimes: An Investigation in the Term Structure of Interest Rates." Journal of Economic Dynamics and Control 12, 2-3: 385-423.

-. 1989. "A New Approach to the Economic Analysis of Nonstationary Time Series and the Business Cycle." Econometrica 57: 357-384.

Harvey, Andrew C. 1990. The Econometric Analysis of Time Series. 2nd edition. Vol. 1. Cambridge: The MIT Press.

Harvey, Andrew C., and Siem Jan Koopman. 1992. "Diagnostic Checking of UnobservedComponents Time Series Models." Journal of Business and Economic Statistics 10, 4: 377 389.

Harvey, David, Neil Kellard, Jakob Madsen and Mark Wohar. 2010. "The Prebisch-Singer Hypothesis: Four Centuries of Evidence." The Review of Economics and Statistics 92, 2: 367-377.

Headey, Derek, and Shenggen Fan. 2008. "Anatomy of a Crisis: The Causes and Consequences of 
Surging Food Prices." Agricultural Economics 39, 1: 375-391.

Hotelling, Harold. 1931. "The Economics of Exhaustible Resources." Journal of Political Economy 39, 2: 137-175.

Kim, Tae-Hwan, Stephan Pfaffenzeller, Anthony Rayner, and Paul Newbold. 2003. "Testing for Linear Trend with Application to Relative Primary Commodity Prices." Journal of Time Series Analysis 24, 5: 539-551.

Leon, Javier, and Raimundo Soto. 1997. "Structural Breaks and Long-Run Trends in Commodity Prices." Journal of International Development 9 , 3: 347-366.

Lumsdaine, Robin L., and David H. Papell. 1997. "Multiple Trend Breaks and the Unit Root Hypothesis." Review of Economics and Statistics 79, 2: 212-218.

Mitchell, Donald. 2008. "A Note on Rising Food Prices." Policy Research Working Paper Series 4682. Washington DC: World Bank.

Ocampo, José Antonio, and María Ángela Parra. 2003. "The Terms of Trade for Commodities in the Twentieth Century." CEPAL Review 79: 7-35.

Perron, Pierre. 1989. "The Great Crash, the Oil Price Shock, and the Unit Root Hypothesis." Econometrica 57, 6: 1361-1401.

—. 1997. "Further Evidence on Breaking Trend Functions In Macroeconomics Variables." Journal of Econometrics 80, 2: 355-385.

Pfaffenzeller, Stephan, Anthony Rayner, and Paul Newbold. 2007. "A Short Note on Updating the Grilli and Yang Commodity Price Index." World Bank Economic Review 21, 1: 151-163.

Powell, Andrew. 1991. "Commodity and Developing Country Terms of Trade: What Does the Long Run Show?" The Economic Journal, 101, 409, 1485-1496.

Prakash, Adam. 2011. Safeguarding Food Security in Volatile Global Markets. Rome: FAO.

Prebisch, Raul. 1950. "The Economic Development of Latin America and Its Principal Problems." Economic Bulletin for Latin America 7: 1-12.
Radetzki, Marian. 2006. "The Anatomy of three Commodity Booms." Resources Policy 31, 1: 56-64.

Reinhart, Carmen M., and Peter Wickham. 1994. "Commodity Prices: Cyclical Weakness or Secular Decline?" IMF Staff Papers 41, 2.

Roache, Shaun K. 2010. "What Explains the Rise in Food Price Volatility?" IMF Working Paper 10/129. Washington DC: International Monetary Fund.

Sapsford, David, Prabirjit Sarkar, and Hans W. Singer. 1992. "The Prebisch-Singer Terms of Trade Controversy Revisited." Journal of International Development 4, 5: 315-332.

Singer, Hans W. 1950. "Comments to the Terms of Trade and Economic Development." Review of Economics and Statistics 40, 1: 84-89.

Stigler, Matthieu. 2011. "Commodity Prices: Theoretical and Empirical Properties." In Safeguarding Food Security in Volatile Global Markets, edited by Adam Prakash, 29-47. Rome: FAO.

Teräsvirta, Timo. 2006. "Nonlinear Univariate Time Series Models." In Palgrave Handbook of Econometrics, edited by Terence Mills and Kerry Patterson, 396-424. Basingstoke, UK: Palgrave MacMillan.

World Bank. 1988. Report on World Development 1988. Management of the Global Economy: Opportunities and Risks, Public Finance and Development, Development Indicators in the World Washington DC: World Bank.

Zanias, George P. 2004. "Testing for Trends in the Terms of Trade between Primary Commodities and Manufactured Goods." Journal of Development Economics 78, 1: 49-59.

Zivot, Eric, and Donald W. K. Andrews. 1992. "Further Evidence on the Great Crash, the OilPrice Shock, and the Unit-Root Hypothesis." Journal of Business and Economic Statistics 10, 3: 251-270. 


\section{APPENDICES}

\section{APPENDIX I}

\section{Table A.1 Comparison of the factors explaining the evolution of commodity prices and the global food crisis of 2005-2008}

\begin{tabular}{|c|c|c|c|}
\hline $\begin{array}{l}\text { Common long- } \\
\text { term factors }\end{array}$ & $\begin{array}{l}\text { Specific factors } \\
\text { of the food crisis }\end{array}$ & Strengths & Weaknesses \\
\hline \multirow[t]{3}{*}{$\begin{array}{l}\text { Progressive shift } \\
\text { in the interna- } \\
\text { tional hierarchy }\end{array}$} & $\begin{array}{l}\text { Growth in demand } \\
\text { from China and India }\end{array}$ & Partial factor of rising oil prices. & $\begin{array}{l}\text { Self-sufficiency of China and India } \\
\text { in major cereals. No increase in } \\
\text { imports of basic food commodities. }\end{array}$ \\
\hline & $\begin{array}{l}\text { Depreciation of the } \\
\text { dollar }\end{array}$ & $\begin{array}{l}\text { The index of real agricultural prices, } \\
\text { weighted by trade for the U.S. de- } \\
\text { preciated by } 20 \% \text { over the period } \\
2002-2007 \text {. The U.S. dollar and } \\
\text { commodity prices are covariant. }\end{array}$ & $\begin{array}{l}\text { No significant weakness. Mitchell } \\
\text { (2008) calculates that the depre- } \\
\text { ciation of the dollar might explain } \\
20 \% \text { of the increase in international } \\
\text { prices. }\end{array}$ \\
\hline & Export restrictions & $\begin{array}{l}\text { Increases in rice prices followed re- } \\
\text { strictions on exports from countries } \\
\text { representing } 40 \% \text { of world exports. }\end{array}$ & $\begin{array}{l}\text { Wheat, corn and soybeans under- } \\
\text { went price increases before the } \\
\text { introduction of export restrictions. } \\
\text { The biggest participants in the } \\
\text { market imposed no restrictions. }\end{array}$ \\
\hline \multirow[t]{5}{*}{$\begin{array}{l}\text { Ecological } \\
\text { transition and re- } \\
\text { source depletion }\end{array}$} & Climatic shocks & $\begin{array}{l}\text { Fifty to sixty percent decrease } \\
\text { in Australian production in } 2005 \\
\text { and 2006, lower production in } \\
\text { the United States, Russia, and the } \\
\text { Ukraine. }\end{array}$ & $\begin{array}{l}\text { Explanation valid for wheat only. } \\
\text { The production shock is not out- } \\
\text { standing. }\end{array}$ \\
\hline & $\begin{array}{l}\text { Productivity slow- } \\
\text { down }\end{array}$ & $\begin{array}{l}\text { Slowdown in growth of rice, wheat } \\
\text { and corn productivity over the previ- } \\
\text { ous twenty years. }\end{array}$ & $\begin{array}{l}\text { There is no evidence that growth in } \\
\text { demand exceeded growth in sup- } \\
\text { ply. }\end{array}$ \\
\hline & Biofuel demand & $\begin{array}{l}\text { Rapid increase since } 2003 \text { (up to } \\
25 \% \text { of corn production in the U.S. } \\
\text { in 2007). }\end{array}$ & $\begin{array}{l}\text { Strong for corn, less for wheat and } \\
\text { other grains, despite substitution } \\
\text { effects. }\end{array}$ \\
\hline & Higher oil prices & $\begin{array}{l}\text { Increase which preceded increases } \\
\text { in commodity prices. Explains a } \\
\text { large part of the costs of transport, } \\
\text { particularly for wheat and corn. }\end{array}$ & $\begin{array}{l}\text { No significant weakness. Effects } \\
\text { may dissipate more slowly due to } \\
\text { substitution effects on the demand } \\
\text { for bio fuel. }\end{array}$ \\
\hline & Speculation & $\begin{array}{l}\text { Coincidence of an increase in finan- } \\
\text { cial activity and rising prices. }\end{array}$ & No causal link shown. \\
\hline \multirow[t]{2}{*}{$\begin{array}{l}\text { Financialization } \\
\text { of raw mate- } \\
\text { rial commodity } \\
\text { markets }\end{array}$} & $\begin{array}{l}\text { Declining stock } \\
\text { inventories }\end{array}$ & $\begin{array}{l}\text { Low stock inventory levels associ- } \\
\text { ated with greater instability. Stock } \\
\text { levels fell before the food crisis. }\end{array}$ & $\begin{array}{l}\text { If China is excluded, the decline } \\
\text { in stock inventories is much less } \\
\text { pronounced. Decline in stocks is a } \\
\text { manifestation of other factors. }\end{array}$ \\
\hline & Low interest rates & $\begin{array}{l}\text { Tendency towards substitution of } \\
\text { storable commodities in investment } \\
\text { portfolios. }\end{array}$ & $\begin{array}{l}\text { Wheat and oil stock inventories } \\
\text { are reasonably high but other food } \\
\text { commodities are low. No uniquivo- } \\
\text { cal relationship between futures } \\
\text { prices and purchase prices. }\end{array}$ \\
\hline
\end{tabular}

Source: Table created from that of Headey and Fan, 2008. 


\section{APPENDIX II: SOURCES}

The data used in the literature are, in general, the commodity price data collected in the global markets. Commodity prices deflated by an index of manufactured goods' unit values, a trade-weighted index of the five major developed countries' (France, Germany, Japan, United Kingdom, and United States) exports of manufactured commodities to developing countries (Manufacturing Unit Value index, index noted as MUV). This allows an indicator of changes in the purchasing power per unit of commodities, and globally, of changes in the terms of trade for commodities, to be constructed.

In the context of this article, we use annual commodities prices indexes beginning in 1900 proposed by Grilli and Yang (1988), and extended by Pfaffenzeller et al. until 2007. The price indices of commodities and agricultural food commodities are derived from a weighted average of price indices respectively comprising 24 commodities and 11 agricultural food commodities. ${ }^{18}$ The weights are based on each commodity's average export share during the 1977-1979 base period.

The price indices of commodities and agricultural food commodities and the price index for manufactured exports by developed countries are extended to 2010 from a series of price indices extracted from databases of the World Bank (Global Economic Monitor Commodities) ${ }^{19}$ and the International Monetary Fund (World Economic Outlook). ${ }^{20}$ We retain the weightings defined in Pfaffenzeller et al. (2007).

\section{APPENDIX III: MODELING OF A TIME SERIES WITH A KALMAN FILTER AND IDENTIFICATION OF STRUCTURAL BREAKS}

We use a state-vector model (Harvey 1990) with a state equation and an observation equation.

The equation of state: $\alpha_{t}=G_{t-1} \alpha_{t-1}+w_{t-1}$ describes the internal dynamics of the model.

$\alpha_{t}$ is the state vector, $G_{t}$ is the transition matrix and $\left(\boldsymbol{w}_{t}\right)$ is a Gaussian noise vector with zero mean and diagonal variance-covariance matrix.

\footnotetext{
18. The commodities examined include eleven agricultural food commodities - bananas, beef, cocoa, coffee, lamb, corn, palm oil, rice, sugar, tea, and wheat; seven non-food commodities - cotton, leather, jute, rubber, wood, tobacco, and wool; six metals - aluminum, copper, lead, silver, tin, and zinc.

19. http://econ.worldbank.org/WBSITE/EXTERNAL/EXTDEC/0,menuPK:476823 pagePK:64165236 piPK:64165141 theSite PK:469372,00.html

20. http://www.imf.org/external/pubs/tt/weo/2011/02/weodata/index.aspx
} 
The observation equation: $Y_{t}=H_{t} \alpha_{t}+\varepsilon_{t}$ connects the observed variable $Y_{t}$ (here the series of data) to the state vector $\alpha_{t}$.

$\varepsilon_{t}$ denotes a scalar Gaussian white noise with zero mean, variance $\sigma_{\varepsilon}^{2}$ and non-correlated with $\left(\boldsymbol{w}_{\boldsymbol{t}}\right)$.

This method takes into account a trend that moves along a "locally linear model" described by the equations:

$$
\begin{aligned}
& \mu_{t}=\mu_{t-1}+\beta_{t-1}+\eta_{t} \\
& \beta_{t}=\beta_{t-1}+\xi_{t}
\end{aligned}
$$

$\mu_{t}$ is called the level and represents the stochastic level of the trend at time $t$.

$b_{t}$ is the stochastic slope of the trend at time $t$.

$\left(\eta_{t}\right)$ is a Gaussian white noise with zero mean and variance $\sigma_{\eta}^{2}$.

$\left(\xi_{t}\right)$ is a Gaussian white noise with zero mean and variance $\sigma_{\varsigma}^{2}$.

$\left(\eta_{t}\right)$ and $\left(\xi_{t}\right)$ are independent.

For purely technical reasons, the cycle is modeled by two processes $\left(\kappa_{t}\right)$ and $\left(\kappa_{t}^{*}\right)$ :

$$
\left[\begin{array}{l}
\gamma_{t} \\
\gamma_{t}^{*}
\end{array}\right]=\rho\left[\begin{array}{cc}
\cos f & \sin f \\
-\sin f & \cos f
\end{array}\right]\left[\begin{array}{l}
\gamma_{t-1} \\
\gamma_{t-1}^{*}
\end{array}\right]+\left[\begin{array}{c}
\kappa_{t} \\
\kappa_{t}^{*}
\end{array}\right]
$$

$f$ is the cycle frequency in radians $(0<f<\pi), \rho$ is the damping factor.

$\left(\kappa_{t}\right)$ is a Gaussian white noise with zero mean and variance $\sigma_{\kappa}^{2}$.

$\left(\kappa_{t}^{*}\right)$ is a Gaussian white noise with zero mean and variance $\sigma_{\kappa^{\prime}}^{2}$. We assume equal variances $\left(\sigma_{\kappa}^{2}=\sigma_{\kappa^{\prime}}^{2}\right)$ and independence of noises $\left(\kappa_{t}\right)$ and $\left(\kappa_{t}^{*}\right)$.

Under these conditions, the equation of state is:

$$
\alpha_{t}=\left[\begin{array}{l}
\mu_{t} \\
\beta_{t} \\
\gamma_{t} \\
\gamma_{t}^{*}
\end{array}\right]=\left[\begin{array}{cccc}
1 & 1 & 0 & 0 \\
0 & 1 & 0 & 0 \\
0 & 0 & \rho \cos f & \rho \sin f \\
0 & 0 & -\rho \sin f & \rho \cos f
\end{array}\right]\left[\begin{array}{c}
\mu_{t-1} \\
\beta_{t-1} \\
\gamma_{t-1} \\
\gamma_{t-1}^{*}
\end{array}\right]+\left[\begin{array}{c}
\eta_{t} \\
\xi_{t} \\
\kappa_{t} \\
\kappa_{t}^{*}
\end{array}\right]
$$

The transition matrix is given by:

$$
\left[\begin{array}{cccc}
1 & 1 & 0 & 0 \\
0 & 1 & 0 & 0 \\
0 & 0 & \rho \cos f & \rho \sin f \\
0 & 0 & -\rho \sin f & \rho \cos f
\end{array}\right]
$$


The observation equation is: $Y_{t}=\left[\begin{array}{llll}1 & 0 & 1 & 0\end{array}\right] \alpha_{t}+\varepsilon_{t}$.

The observation equation reflects the decomposition of the series into a component of trend, a cyclical component and an irregular component.

The model parameters represented by the vector $\Theta=\left(\rho, f, \sigma_{\eta}^{2}, \sigma_{\xi}^{2}, \sigma_{\kappa}^{2}, \sigma_{\varepsilon}^{2}\right)$ are estimated by the method of maximum likelihood.

Once the parameters are estimated, the Kalman filter allows a recursive calculation of the trend component, the cyclical component, and the irregular component, on a given date, based on information known up to that date. These components can be smoothed, at a given date, using the entire data set. This method is used to estimate the components of the series on a given date.

Auxiliary residuals introduced by Harvey (Harvey and Koopman 1992) correspond to smoothed estimations of the different perturbations of the local linear trend model. They are divided into three categories:

- Irregular auxiliary residuals, determined by:

$\frac{\hat{\varepsilon}_{t}}{\sqrt{\operatorname{Var}\left(\hat{\varepsilon}_{t}\right)}}$ where $\hat{\varepsilon}_{t}$ denotes a smoothed estimate of $e_{t}$, allowing potential outliers in the series to be detected.

- Auxiliary residuals of level, determined by:

$\frac{\hat{\eta}_{t}}{\sqrt{\operatorname{Var}\left(\hat{\eta}_{t}\right)}}$ where $\hat{\eta}_{t}$ denotes a smoothed estimate of $\eta_{t^{\prime}}$ allowing potential structural breaks in level in the series to be detected.

- Auxiliary residuals of slope, determined by:

$\frac{\hat{\xi}_{t}}{\sqrt{\operatorname{Var}\left(\hat{\xi}_{t}\right)}}$ where $\hat{\xi}_{t}$ denotes a smoothed estimate of $\xi_{t}$ allowing potential structural breaks in the slope of the series to be detected. Auxiliary residuals of slope are employed less than auxiliary residuals of level.

High values for these residuals correspond to outliers or structural breaks depending on whether they are irregular residuals of level or of slope.

To identify a potential candidate date for a level break, we select time periods of auxiliary level residuals that have absolute values exceeding some value $t$. 


\section{APPENDIX IV: MARKOV REGIME SWITCHING MODELS}

There are different types of Markov switching models, among which the most used are MS-DR models (Markov Switching Dynamic Regression), MS-AR (Markov Switching Autoregressions) or MS-ARMA.

In this article, we use MS-DR models, of which the general representation is:

$$
Y_{t}=\mu_{s_{t}}+\sum_{i=1}^{p} \alpha_{t} Y_{t-i}+\varepsilon_{t}
$$

where $Y_{t}$ denotes the observed series and $e_{t}$ a random variable having a normal distribution $\mathrm{N}\left(0, \sigma_{s t}\right)$.

The sequence $\left(e_{t}\right)$ is assumed to be independent. $\sigma_{S \mathrm{t}}$ is the standard deviation of $e_{t}$ in the state of the system at time $t$, or $S_{t}$.

The $S_{t}$ process is modeled by a homogeneous Markov chain with $N$ states called regimes. The transition probabilities satisfy:

$$
P\left(S_{t}=j \mid S_{t-1}=i\right)=P\left(S_{1}=j \mid S_{0}=i\right) \text { for all } t \text { and for } i, j=0, \ldots, N-1 \text { (homoge- }
$$
neity of the chain) and $\sum_{j=0}^{N-1} P\left(S_{t}=j \mid S_{t-1}=i\right)=1$ for all $i=0, \ldots, N-1$.

More specifically, the model we use here is: $Y_{t}=\mu_{s t}+\varepsilon_{t}$.

Each regime can be characterized by a constant $\mu_{S t}$ and a variance $\sigma_{S t}$ specific to each regime. The variance can therefore also undergo a change of regime. The estimation of model parameters is based on the principle of maximum likelihood. 